\title{
Pandemic Era, Education Support Technology: The Potential for Augmented Reality in Science Learning
}

\author{
Hana Puspitasari ${ }^{1, *}$ I Gusti Putu Suryadarma ${ }^{2,}$ Pujianto $^{3}$ \\ ${ }^{I}$ Master of Natural Science Education, Faculty of Mathematics and Natural Sciences, Universitas Negeri \\ Yogyakarta, Indonesia \\ ${ }^{2}$ Department of Biology Education, Faculty of Mathematics and Natural Sciences, Universitas Negeri Yogyakarta, \\ Indonesia \\ ${ }^{3}$ Department of Physics Education, Faculty of Mathematics and Natural Sciences, Universitas Negeri Yogyakarta, \\ Indonesia \\ *Corresponding author. Email: hanapuspitasari.2019@student.uny.ac.id
}

\begin{abstract}
Currently, all sectors of life are limited, working from home to schooling from home due to the spread of the coronavirus or covid-19. Many victims have died due to contracting this virus. Therefore, all activities that create crowds are tightened and reduced, all students from elementary level to college level are learning online through the help of technological sophistication. From the existing prolems, in the article, we provide a systematic literature review that analyzes the use of AR technology concerning the natural science context to highlight the importance of the role for students, therefore it can be used as learning support during the Covid-19 pandemic. We use the approach developed by Tranfield to conduct a systematic literature review, which followed the selection of articles that fit the keyword and analyzed in depth. The resulting development of AR can be used in learning as a means of making it easier for students to understand concepts that are considered abstract, so that it can improve knowledge, motivation, achievement, and experience for students.
\end{abstract}

Keywords: Augmented reality, Science learning, Covid-19

\section{INTRODUCTION}

At the end of 2019, all parts of the world were stirred up by new cases, no longer cases concerning politics or economics, cases that had an impact in all sectors were temporarily halted. Large-scale cases caused by the virus have occurred several times, such as the emergence of bird flu (H5NI) infected poultry farms occurring in 1990 [1]. In 1997, this case resulted in the deaths of several people in Hong Kong for the first time until it has expanded into various countries [2]. In 2009, as many as 642 people from the United States died from the H1N1 virus or swine flu [3] who were on alert one, the SARS case that occurred in 2003 caused public unrest resulting in the cancellation of visits between regions of the country which triggered a weakening of the economic sector. No less excitement, the Ebola virus attacked several regions in 2014 resulted in hundreds of thousands of people dying and the re-emergence in 2018 in the Congo region which killed 20 people [4]. At the end of 2019, a new case emerged from Wuhan, China, namely the coronavirus or Covid-19, the spread of this virus so rapidly caused to exposed millions people [5], WHO data shows that as many as $39,596,858$ positive cases of Covid-19 and 1,107,374 people died until 18 October 2020. Cases caused by some of these viruses caused limited movement to have an impact that changed the life order such as the Covid-19 pandemic that was happening. Covid-19 pandemic has a very significant impact on human life from the economic, political, religious, educational, and industrial sectors, thus changing human behavior patterns into social distancing or maintaining distance [6] to reduce the transmission rate of this case. The result of this pandemic period has limited movement, one of which is education.

Learning that was originally carried out directly in schools with real interactions between teachers and students, as a result of the Covid-19 pandemic limiting the space for interaction, therefore, learning uses online technology assistance to continue the teaching 
and learning process. All types of learning activities are carried out online starting from providing material, tests, to practicum virtually. Everyone is required to be technology literate in the era of the Covid-19 pandemic, the understanding of digital technology for children in the millennial era has been embedded since they were in the womb, because in the era of revolution 4.0 it has been controlled by digital technology [7]. So the students are accustomed to using this type of technologically sophistication, especially smartphones, but it is not uncommon for children who are not technology literate because they are in an unsupportive environment. This portrait demands both teachers, students, and parents to be technologically literate, not only in the education sector which relies on technological sophistication, almost all areas of life rely on this progress when the pandemic takes place. This makes some subjects such as science which requires practicum in the laboratory cannot be carried out due to the closure of laboratory access which creates a challenging situation and provokes confusion [8]. Virtual laboratories have been developed and used before the pandemic case, but cannot completely replace physical laboratories, where students feel more directly and in real life using real experiments and provide experiences like a scientist.

Pandemic conditions require people who have no interest to stay at home, increasing the use of digital technology access, especially for students. The younger generation, especially students, should understand and be able to make policies in absorbing information about the benefits of digital technology used in everyday life, such as use for online learning. Technology producers are starting to consider critically so that the younger generation can acquire skills and innovations from the technology used, such as designing and building digital technology that spurs competence [7], [9], such as digital mini laboratory technology. Therefore, it being able to support online learning is not monotonous with assignments, but students can interact directly as if students are learning like in school. Online learning that has been going on for months has resulted in students feeling bored which results in laziness and physical pressure. According to [10], time spent on social media activities causes increasing anxiety, depression, and impaired mental health, just as during the pandemic Chinese media announced that there was a surge in psychological cases. It can happen to children because they feel bored with monotonous learning done online at home. With the existence of digital technology innovation in the education world, not only giving assignments but also it can support a learning variation.

The purpose of this article is to provide a systematic literature review regarding learning support technology in pandemic conditions, especially Covid19 through 3D novelty technology in the form of augmented reality.

The systematic literature review focuses on the similarities and differences of the objects used and examines various studies according to predetermined keywords [11] so that, based on various literature studies discussed will find relationships to conclude [12]. Systematic search process using criteria that must be included or must have from every article raised and exclusion of these articles is not included in predetermined categories [13].

\section{RESEARCH METHODS}

Systematic literature review (SLR) used to be the method of this articl. It developed by Tranfield, Danyer, and Smart (2003), often called the Tranfield approach. This approach leads to three main stages, namely planning, execution, and reporting dissemination [13], [14] The first step, namely the stage planning, this stage begins by determining search keywords to make it easier to select books, journal articles, and proceedings. As seen from the title, abstract, and keywords. Determination of search keywords based on the outline of this study, namely the focus on "educational support technology in the covid-19 era" or "augmented reality in education."

The second step is the stage, execution in this process, starting the search for supporting research sources that are used as an analysis in the form of books, journal articles, or proceedings but focus on searching in the form of journal articles and proceedings as support. Search based on existing databases in Scimago ranking because it is more recognized in publications and reliable sources of truth. Of the many search pages that exist based on rankings in the Scimago Journal \& Country Rank, we use the search links on Elsevier, Wiley, Springer, and Science Direct. As well as searches that are open access or are free of charge. The search results from the three pages obtained 489.952 publications, then they were selected based on the range of years, namely the last 10 years (2012-2020) there were 45.553 publications. The next stage of selection is based on type of the source, namely in the form of journal articles, there are 41.605 publications, of which many publications are selected using the English language either from the title, abstract or content. We take open- 
access journal articles based on the keywords that have been set in 315 publications. The steps developed can be seen in Figure 1.

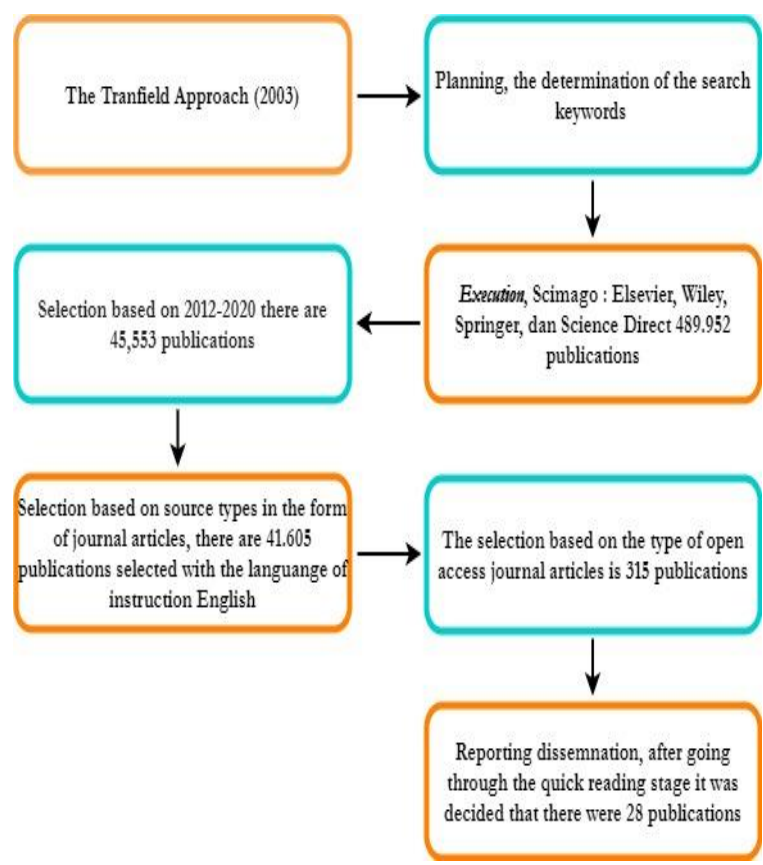

Figure 1 Process systematic literature review

The third step in the Tranfield approach is reporting dissemination, at this stage, we selected from the last search there were 315 publications, only 28 publications after reviewing the literature and paying attention to the criteria attached (Table 1). A total of 28 publications are divided into the years 2012-2020, namely 2012 (2), 2013 (4), 2014 (4), 2015 (2), 2016 (2), 2017 (1), 2018 (3), 2019 (4), 2020 (6). Our search in 2020 focuses on conditions that are currently happening, namely the Covid-19 pandemic so that the explanation leads to this case which has an impact on education.

\section{LITERATURE REVIEW}

The purpose of this article is to provide information regarding a literature review regarding the role of technology in education during the Covid-19 pandemic through the help of augmented reality as a novelty plan by seeing the role of this technology used before the pandemic shows positive results in learning. From Table 1, we attached to make a summary according to articles published by authors related to technology, especially augmented reality and the Covid-19 pandemic.

Learning both indoors and in class is a step that is usually used as formal teaching and learning with oneway interaction between teachers and students.
Learning that is carried out outside the classroom, such as museums does not provide introductory tours that can understand the students' ability to capture explanations [15]. Advances in technology that are increasingly advanced with the use of mobile phones, especially smartphones, can develop a technology that is easy to use by students and provide new experiences without having to go to the museum directly, namely a sophisticated 3D technology, namely augmented reality. This technology is used to help explain the routes that exist in the museum, besides that this application can record the learning process and increase students' abilities both knowledge and student motivation [16]. The subject of science learning and technology integration provides experiences both regarding student motivation and cognition, the results of this study indicates that using this application provides an effective plan. The concept of using the museum-based augmented reality application provides knowledge that is relevant to the experience and directs students to experience learning in science and stechnology friends to strengthen learning motivation.

Using augmented reality based on images provides a positive aspect in science learning by showing positive aspects of interaction and learning experiences. Also, it shows a positive and useful attitude, from AR application-based learning gives the impression those students have practical skills in the laboratory and understanding concepts [17]. AR technology is very useful in the world of education because it applies to real life and uses the sophistication of remote laboratories. 3D type technology helps students connect exploration in the real world in virtual form with information that is more complete and easily understood by students. This technology has the potential to connect students to understand the information presented virtually from various perspectives. The negative effect is very low in using AR, most students get new experiences and feel challenged in learning like this [18]. Using AR technology in science education has a high level of practicality for inquiry-based learning [19].

AR technology can be developed in science learning materials such as in solar system lessons, with the help of 3D technology students can visualize the shape of the solar system as if it looks real, not just pictures, of course, equipped with supporting information. Therefore, students don't feel confused in presenting the media. AR technology is concerned with the relationship between content and activity in a cognitive manner. Students think that learning to use AR technology will feel more attractive and fun [20]. This type of AR book is used as auxiliary material in the science material at the anatomy section making it 
easier for students to describe body parts. The research results show that using this technology can provide a motivational stimulus to students compared to conventional methods and most students are also interested in learning, this is supported by Lee's (2008) research data that $62 \%$ of students feel happy, interested, or comfortable using this type of media. AR. In addition to these benefits, it can help reduce workplace accidents in the laboratory and reduce the cost of purchasing materials [21]. Using AR is also used at the college level, most students feel interested and comfortable inside it supports increasing motivation to attend lectures, this is supported by research [22] that $65 \%$ of students are motivated to take learning with supporting technology of the AR type. AR technology has the potential support in teaching and learning, with using media assistance like this can improve both cognitive and affective abilities. The challenge in using AR is considered very small because its influence in education is very high, it provides visible benefits in the types of material that are considered abstract, difficult to describe directly such as in science from biology, chemistry, and physics [23].

In addition to motivation and cognitive abilities, using AR can be used as a measure of student achievement and problem-solving abilities. The study used a quantitative method of 147 students at level 7 which was divided into two treatments, namely the experimental class and the control class. The experimental class has a superior cognitive level compared to the control class, apart from being measured regarding thinking ability, it can be seen from the measure of the ability to solve problems that students have a positive attitude. Using AR can help students be more confident in solving problems and confident in making decisions. Therefore, using AR can help students improve achievement and be able to develop skills in solving problems [24]. Supported by Lu's research (2014) $38 \%$ of pretest-posttest measurements using AR can improve student achievement in the field of knowledge.

From the results of other studies, it shows that the use of AR technology in education is $31 \%$ elementary school level and $29 \%$ junior high school level in the form of games, while $20 \%$ of high school uses this type of game as well as a continuation of the previous level. Usage among universities is low, around $8 \%$ only in the fields of design and physics. Depend on the object of learning, the most user AR is in science and biology, which is around $38 \%$, can provide more prominent benefits, namely both from the concept of real knowledge and students can observe an object in real terms. Furthermore, it can be used at home.
Therefore, this type of media makes it easier for students to study formally at school and informally at home. This matter is supported by data that show $42 \%$ of $\mathrm{AR}$ is used outside the classroom environment and $35 \%$ in the classroom, if done in the classroom, students can play face to face and under the direction of the teacher. Students can solve problems and can collaborate with classmates besides getting help from the teacher. It means, the students cannot use this type of media without the attention of the teacher. Students can use it at home so that they can study together with directions from their family if equipped with usage guidelines [25].

Using AR gives a real impression of an abstract concept. This technology is ideal for providing a conceptual experience that cannot be observed. Memory retention is also a benefit obtained by using AR-based learning, giving students the ability to remember longer than other learning methods. AR provides three important elements for users, namely real, contextual, and vision haptic visualization so that, it supports long-term memory in the brain [26], [27]. The next benefit is autonomy, real and virtual world collaboration can increase students' independence by seeing the abilities and motivations that are naturally formed in using modern technology [28]. No less important is the ability to collaborate with peers and learn content, accessibility, and creativity created by the collaboration between students and technology. [29]

Technology does not only have a positive impact on its users, no matter how small it has a negative impact as well. Using AR technology in education has a negative impact. However, it is not worth the benefits it gets. The first impact is the difficulty in using AR technology in the classroom if the marker is a location [30]. Students are required to focus on this technology, therefore they often ignore instructions because they find learning fun to forget important information conveyed [31]. Students are enthusiastic about participating in AR-assisted learning technology because they find it more interesting to be able to interact with real-world objects following the instructions given virtually. Guiding students to observe and complete assignments in a relevant and easy to understand manner is not boring. Helping students to focus more on detailed observations than direct observations. And also helping students to generate confidence in abilities that can improve academic skills [32].

AR technology is a game-like tool through communication technology that is made interactive so that it provides a long-term and motivating experience. 
$50 \%$ of teachers said that AR used in learning is a type of instruction and a new learning method [33]. AR technology makes science education more productive, fun, and interactive and teaches students to discover both new thinking and discovery activities to improve constructivist skills that are more flexible. The creators designed this media in order that students can have higher thinking skills through the ability to analyze, evaluate, and create. Because this technology is made to facilitate experimentation and give real form to abstract content [34].

The type of AR technology used is an anatomical development to make it easier for health students to learn the ins and outs of the body in the form of $4 \mathrm{D}$, there is an increase in the value of attention, confidence, and satisfaction, respectively, an increase of $31 \%, 11 \%$, and $13 \%$, increasing learning motivation by $14 \%$. Also, there is a decrease in the value of the relevant factor [35]. AR technology provides facilities for students to do learning anywhere to gain knowledge. It is possible to use it as a "flipped classroom". Students can study at home by face-toface meetings and make a discussion about things that are still in doubt and carry out collaborative learning [36]. Most students find it difficult to study biology when they read books that are difficult to understand because they look abstract. Developing e-book technology makes learning easier and more interactive and motivates students to gain a wider experience. One of the supporting media parts of the e-book is AR, the integration of using printed books with AR technology makes it easier for students to understand abstract material [37].

The effect of covid-19 has an impact on the world of education to become an online learning system, both from the approach to the learning design that has completely changed to blinded learning. Online learning designs are made with care by paying attention to several important factors, such as previous experiences and students' understanding of using online learning. This matter is fully supported with the help of technology in online learning to be an important factor when the pandemic hits, besides learning content and curriculum with an approach that can provide active and effective learning [38]. Online learning has led to distance learning because of the effects of the massive closure of schools and colleges. Education has become an emergency material and technology has been positioned at the forefront of emergency services. Teachers use technology as a means of communicating with students because schools are closed. Of course, every student must have the ability to sort and have skills in using technology effectively and safely to achieve learning goals.
However, when students do not have digital access in their home environment, they will feel difficulty in facing a pandemic. This matter can have a negative impact [39].

Using technology for both students and workers is increasing because students have to do school online and workers do work from home online. It's the effects of the covid-19 pandemic that has not ended. This condition affects their physical and mental health during all activities at home. Of course, using technology affects their mental health in the form of both positive and negative effects. The positive effects obtained in using technology during the pandemic are increased social interaction, social support, and social relations. Of course, through the help of social media. While the negative effects caused by this condition are depression and increased anxiety [40]. This matter is because they are bored with activities that only can be done in the house or around the house. However, this case can be overcome by providing a schedule of daily activities and boredom can be overcome, and also using social media can be reduced. Using technology that was petrified in education during covid-19, one of which is in the field of biology, namely augmented reality, with the help of technology, it can visualize abstract things to be real and very easy to use. The benefit of the technology deployment is very easy to do remotely, can be easily used on students' smartphones. Because of this learning can continue. Students are easier to understand without having to do experiments in the laboratory, they can do it in arranging the contents that the teacher wants to emphasize. The learning seems interesting as if students see an imagined object directly in 3D, increasing student motivation in doing online learning [41].

\section{RESULT AND DISCUSSION}

After conducting a review of 28 articles, we grouped them into several categories that were frequently raised in the field of education. We show the types of categories in Table 2 that appear in the article. In Table 1 , those categories are namely increasing knowledge points (14.28\%), increasing motivation points in participating learning $(25 \%)$, ease of use both indoors and outdoors and ease of use in access $(28.58 \%)$, users get new experiences and give an interesting impression in learning (17.86\%), which can improve problem-solving and collaborative abilities (7.14\%). Apart from the five categories, several articles discuss more deeply the aspects obtained in using AR technology in education in the 
form of positive aspects (14.28\%) and negative aspects (14.28\%) in Table 2.

Table 1. Distribution of the use of augmented reality technology in education

\begin{tabular}{|l|l|l|}
\hline \multicolumn{1}{|c|}{ Category } & \multicolumn{1}{|c|}{$\begin{array}{c}\text { Number of } \\
\text { article }\end{array}$} & Percentage (\%) \\
\hline Knowledge & $3,8,9,18$ & 14.28 \\
\hline Motivation & $\begin{array}{l}1,3,7,9,10,20, \\
21\end{array}$ & 25 \\
\hline Ease of use & $\begin{array}{l}5,12,15,22,23, \\
24,25,37\end{array}$ & 28.58 \\
\hline Experience & $4,11,13,14,17$ & 17.86 \\
\hline $\begin{array}{l}\text { Solution to } \\
\text { problem }\end{array}$ & 6,16 & 7.14 \\
\hline
\end{tabular}

Table 2. Aspect distribution

\begin{tabular}{|l|l|l|}
\hline \multicolumn{1}{|c|}{ Category } & \multicolumn{1}{|c|}{$\begin{array}{c}\text { Number of } \\
\text { article }\end{array}$} & Percentage (\%) \\
\hline $\begin{array}{l}\text { Positive } \\
\text { aspects }\end{array}$ & $2,10,18,28$ & 14.28 \\
\hline $\begin{array}{l}\text { Negative } \\
\text { aspects }\end{array}$ & $2,5,19,26$ & 14.28 \\
\hline
\end{tabular}

The results of this research article on the role of $\mathrm{AR}$ in learning are increasing motivation and ease of using media for students of school and college. This matter is very often to be a topic of discussion $(25 \%$ and $28.5 \%$ in articles) because the potential role of AR in learning gives an interesting impression. Therefore, it can invite students to be interested in learning participation and more focus on reducing curiosity about some themes that are considered abstract especially in science. However, several articles state that motivation and knowledge go hand in hand, if there is an increase in knowledge then motivation also increases.

Another analysis that is not less frequent in the discussion of each article is using technology from kindergarten to university level. Ease of use often discusses the ease with which it can be used anywhere both indoors and outdoors so that users don't feel bored, this technology also supports learning both formally and informally. Of course, some articles also discuss the negative aspects that are caused or the difficulties that are found when using AR technology, one of which is the topic of discussion in research, namely the imperfections in making this device so that errors often occur and the instructor or the teacher is not ready to guide students to use this technology so feel overwhelmed. But of course, some teachers are proficient in using AR in learning because there are already instructions on the device, making it easier to use.

No less important is the discussion about the role of AR technology in developing problem-solving and collaboration attitudes. Only a few articles discuss the role of AR in problem-solving and collaboration (6\%). By using this technology assistance student find it easier to solve problems related to daily life besides that it is easier to appreciate abstract objects as real. The example is in chemical processes related to chemical groups and objects concerning biology. Through this problem-solving activity, students can collaborate with peers to explore nature through location-based AR assistance as if it were learning and adventure.

The fact is that some students are still constrained by using AR technology because of the weak signal network that hinders use. Besides, the lack of parents' role in providing direction is also an obstacle when this technology is used at home. Several cases mentioned that parents felt confused and do not care about learning because there is not enough time to guide children to learn and are hampered by work time. So that, this thing can hinder students' motivation to take part in learning, especially during the Covid-19 pandemic. From the results of the review, only one article discusses the role of AR technology in helping students in distance learning but still being able to carry out experiments without having to be done in the laboratory. Besides, the ease in spreading this technology to students and affordability is another advantage. Therefore, students feel they have a new experience in learning that is not monotonous doing online learning activities by doing assignments or through conferences but they are still active in learning by interacting using 3D assistance.

The features in AR development can also be adjusted to the material to be delivered so that it can be right on target in use so that students can more easily capture information and use it easily. Several platforms have also provided online AR technology making it easier for teachers to develop diverse media to support implementing online learning. Every technology developed in supporting of learning. Of course, it has positive and negative aspects but, from the 28 articles that have been discussed, $14.28 \%$ stated that the influence of AR in learning gives a positive impression both for students and teachers, especially for students. 


\section{CONCLUSION}

In this article, we only present a summary of the views of writing on the meaning of AR technology in learning, especially in the field of science, both from elementary school to university levels from various countries. This summary refers to 28 articles that address the role of AR technology in education as well as the quality of the articles published according to Scimago's ranking. In this summary, we go through important stages like from analysis to data collection. From the analysis that has been done, several reflections are important to conclude. Through this summary, we know the developing AR that can be used in learning as a means of making it easier for students to understand concepts that are considered abstract. So that they can improve knowledge, motivation, achievement, and experience. Besides, it can be announced remotely and used anytime and anywhere. So that it can be used when the school is closed and learning virtually at home.

Of course, the important point is to pay attention to the level of material difficulty and the readiness of the technology to be given. Seeing the space around whether it is possible in developing AR and seeing the negative aspects that are generated. Finally, through this article, we thus emphasize that AR technology can be developed at any time in science learning, both from the basic level to high. Through analysis that AR technology is relevant and adapted to the times and needs. So that, it is expected to facilitate and improve the student understanding.

\section{AUTHORS' CONTRIBUTIONS}

H.P,P, and I.S concevied of the presented idea. H.P developed the theory and performed the computations. $\mathrm{P}$ and I.S verified the analytical methods. H.P,P, and I.S contributed to the interpretation of the results. H.P wrote the manuscript with input from all authors. All authors provided critical feedback and helped shape the research, analysis, and manuscript.

\section{REFERENCES}

[1] S. Herfst, E.J.A Schrauwen, M. Linster, et al., Airborne Transmission of Influenza A/H5N1 Virus Between Ferrets, Science 336 (2012) 1534-1541.

DOI: https://doi.org/10.1126/science.1213362

[2] J.C de Jong, E.C.J Claas, A.D.M.E Osterhaus, et al., A pandemic warning?, Nature 389 (1997) 554-555. DOI: https://doi.org/10.1038/39218
[3] F.S Dawood, S. Jain, L. Finelli, et al., Emergence of a Novel Swine-Origin Influrnza A (H1N1) Virus in Humans, The New England Journal of Medicine 360 (2009) 2605-2615. DOI: https://doi.org/10.1056/NEJMoa0903810

[4] P. Mbala-Kigebeni, A. Aziza, N. D Paola, et al., Medical countermeasures during the 2018 Ebola virus disease outbreak in the North Kivu and Ituri Proviences of the Democratic Republic of the Congo: A Rapid Genomic Assessment, The Lancet Infectious Diseases 19 (2019) 648-657. DOI: $\quad$ https://doi.org/10.1016/S14733099(19)30118-5

[5] N. Iivari, S. Sharma, L .Venta-Olkkonen, Digital Transformation of Everday Life: How Covid-19 Pandemic Transformed The Basic Education of The Young Generation And Why Information Management Research Should Care?, International Journal of Information Management 55 (2020) 1-6. DOI: https://doi.org/10.1016/j.ijinfomgt.2020.102183

[6] T. Chang, G. Hong, C. Paganelli, et al., Innovation of Dental Education During COVID19 Pandemic, Journal of Dental Sciences 16 (2021) 15-20. DOI: https://doi.org/10.1016/j.jds.2020.07.011

[7] N. Iivari, M. Kinnula, Empowering children through design and making: towards protagonist role adoption, in: Proceedings of the 15th Participatory Design Conference, vol. 1, Associantion for Computing Machinery, New York, United States, 2018, pp. 1-12. DOI: https://doi.org/10.1145/3210586.3210600

[8] R. Vasiliadou, Virtual Laboratories during Coronavirus (COVID-19) Pandemic, Biochemistry and Molecular Biology Education $48 \quad$ (2020) 482-483. DOI: https://doi.org/10.1002/bmb.21407

[9] I. Marien, J.A. Prodnik, Digital Inclusion and User (Dis)Empowerment: A Critical Prespective, Emerald Insight, 16 (2014) 35-47. DOI: https://doi.org/10.1108/info-07-2014-0030

[10] D.R. Gaarfin, Technology as a Coping Tool during The Coronavirus Disease 2019 (COVID19) Pandemic: Implications and Recommendations, Stres and Health 36 (2020) 555-559. DOI: https://doi.org/10.1002/smi.2975

[11] B.S. Hantono, L.E. Nugroho, P.I, Santoso, MetaReview of Augmented Reality in Education, 
International of Electrical and Electronics Engineers (2018) 312-315. DOI: https://doi.org/10.1109/ICITEED.2018.8534888

[12] A.F. Lai, C.H. Chen, G.Y. Lee, An Augmented Reality-Based Learning Approach to Enchancing Students' Science Reading Performance from The Prespective of The Cognitive Load Theory, Journal of Educational Technology 50 (2018) 232-247.

DOI: https://doi.org/10.1111/bjet.12716

[13] A. Corallo, M. Lazoi, F. Striani, Process mining and Industrial Applications: A Systematic Literature Review, Knowledge and Process Management 27 (2020) 225-233. DOI: https://doi.org/10.1002/kpm.1630

[14] D. Tranfield, D. Denyer, P. Smart, Towards a Methodology for Developing Evidence-Informed Management Knowledge by Means of Systematic Review, British Journal of Management 14 (2003) 207-222. DOI: https://doi.org/10.1111/1467-8551.00375

[15] Y.M. Huang, Y.W. Chou, T.C. Yeh, Activating Natural Science Learning by Augmented Reality and Indoor Positioning Technology, Lecture otes in Electrical Engineering, Springer, Berlin, Heidelberg, 2014, pp. 213-220. DOI: https://doi.org/10.1007/978-94-007-7262-5_27

[16] A.D. Serio, M.B. Ibanez, C.D. Kloos, Impact of An Augmented Reality System on Students' Motivation for A Visual Art Course, Computer and Education 68 (2013) pp. 586-596. DOI:https://doi.org/10.1016/j.compedu.2012.03. $\underline{002}$

[17] K.H. Cheng, C.C. Tsai, Affordances of Augmented Reality in Science Learning: Suggestions for Future Research, Journal of Science Education and Technology 22 (2013) 449-462. DOI: https://doi.org/10.1007/s10956012-9405-9

[18] H.K. Wu, S.W.Y. Lee, H.Y. Chang, J.C. Liang, Currents Status, Opportunities and Challenges Of Augmented Reality in Education, Computer and Education 62 (2013) 41-49. DOI: https://doi.org/10.1016/j.compedu.2012.10.024

[19] T.H.C. Chiang, S.J.H. Yang, G.J. Hwang, An Augmented Reality-based Mobile Learning System to Improve Students' Learning Achievementes and Motivations in Natural
Science Inquiry Activities, Educational Technology and Society 17 (2014) 352-365.

[20] D. Stoyanova, N. Kafadarova, S.S. Petrova, Enchancing Elementary Student Learnng in Natural Science through Mobile Augmented Reality Technology, Bulgarian Chemical Communications 47 (2015) 532-536.

[21] J. Farresr-Torregrosa, J. Torralba, M.A. Jimenez, et al., ARBOOK: Development and Assessment of a Tool Based on Augmented Reality for Anatomy, Journal of Science Education and Technology 24 (2015) 119-124. DOI: https://doi.org/10.1007/s10956-014-9526-4

[22] C.M. Chen, Y.N. Tsai, Interactive Augmented Reality System for Enchancing Library Instruction Elementary Schools, Computer and Education 59 (2012) 638-652. DOI: https://doi.org/10.1016/j.compedu.2012.03.001

[23] M. Akcayir, G. Akcayir, Advantages and Challenges Associanted With Augmented Reality for Education: A Systematic Review of The Literature, Educational Reserach Review 20 (2017) 1-11. DOI: https://doi.org/10.1016/j.edurev.2016.11.002

[24] D. Karagozlu, Determination of The Impact of Augmented Reality Application on The Success And Problem Solving Skills of Students, Quality and Quantity 52 (2018) 2393-2402. DOI: https://doi.org/10.1007/s11135-017-0674-5

[25] J. Li, E.D. Spek, L. Feijs, F. Wang, J. Hu, Augmented Reality Games for Learning: A Literature Review, Interanational Coference on Distributed Ambient and Prevasive Interactions, in Computer Science, Springer, Berlin, Heidelberg, 2017, pp. 612-626. DOI: https://doi.org/10.1007/978-3-319-58697-7_46.

[26] P. Sommerauer, O. Muller, Augmented Reality in Informal Learning Environments: A Field Experiment in A Mathematics Exhibition, Computer and Education 79 (2014) 59-68. DOI: https://doi.org/10.1016/j.compedu.2014.07.013

[27] Y. Liu, D. Holden, D. Zheng, Analyzing students language learning experience in an augmented reality mobile game: an exploration of an emergent learning environment, in: Procedia Social and Behavioral Sciences, vol. 228, Elsevier, Amsterdam, 2016, pp. 369-374. DOI: https://doi.org/10.1016/j.sbspro.2016.07.055 
[28] M.B. Ibanez, A.D. Serio, D. Villaran, C.D. Kloos, Experimenting with Electromagnetism Using Augmented Reality: Impact on Flow Student Experience and Educational Effectiveness, Computer and Education 71 (2014) 1-13. DOI: https://doi.org/10.1016/j.compedu.2013.09.004

[29] K.R. Bujak, I. Radu, R. Catrambone, B. Maclntyre, R. Zheng, G. Golubski, A Psychological Prespective on Augmented Reality in The Mathematics Classroom, Computers and Education 68 (2013) 536-544. DOI: https://doi.org/10.1016/j.compedu.2013.02.017

[30] J. Garzon, J. Pavon, S. Baldiris, Systematic review and meta-analysis of augmented reality in educational settings, Virtual Reality, Springer, Berlin, Heidelberg, 2019, pp. 447-459. DOI: https://doi.or/10.1007/s10055-019-00379-9

[31] I. Radu, Why should my students use AR? A comparative review of the educational impacts of augmented-reality, in: 2012 IEEE International Symposium on Mixed and Augmented Reality (ISMAR), International of Electrical and Electronics Engineers, 2013, pp. 313-314. DOI: https://doi.org/10.1109/ISMAR.2012.6402590

[32] P.H. Wu, G.J. Hwang, M.L. Yang, C.H. Chen, Impact of integrating the repertory grid into an augmented realty-based learning design on students' learning achievements, cognitive load and degree of satisfaction, Interactive Learning Environments, $26 \quad$ (2017) .221-234. DOI: https://doi.org/10.1080/10494820.2017.1294608

[33] G. Molnar, Z. Szuts, K. Biro, Use of Augmented Reality in Learning, Acta Polytechnica Hungarica, 15 (2018) 209-222.

[34] G. Papanastasiou, A. Drigas, C. Skianis, M. Lytras, E. Papanastasiou, Virtual and augmented reality effects on $\mathrm{K}-12$, higher and tertiary education students' twenty first century skills, Virtual Reality, vol.23, Springer, Berlin, Heidelberg, 2019, pp. 425-436. DOI: https://doi.org/10.1007/s10055-018-0363-2
[35] T. Khan, K. Johnston, J. Ophoff, The Impact of an Augmented Reality Application on Learning Motivation of Students, Advances in HumanComputer Interaction 20 (2019) 1-14. DOI: https://doi.org/10.1155/2019/7208494

[36] J. Cabero-Almenara, J. Barroso-Onsuna, C. Llorente-Cejudo, M.M.F. Martinez, Educational uses of augmented reality (AR), in: Sustainability, vol.11, Multidisciplinary Digital Publishing Institute, Basel, Swiss, 2019, pp. 4990. DOI: https://doi.org/10.3390/su11184990

[37] C. Weng, S. Otanga, S.M. Christianto, R.J.C. Chu, Enhancing Students' Biology Learning by Using Augmented Reality as A Learning Supplement, Journal of Educational Computing Research 58 (2019) 747-770. DOI: https://doi.org/10.1177/0735633119884213

[38] J. Sandars, R. Patel, The Challenge of Online Learning for Medical Education During The COVID-19 Pandemic, Interantional Journal of Medical Education 11 (2020) 169-170. DOI: https://doi.org/10.5116/ijme.5f20.55f2

[39] B. Williamson, R. Eynon, J. Potter, Pandemic Politics, Pedagogies and Practices: Digital Technologies and Distance Education During The Coronavirus Emergancy, Learning, Media and Technology 45 (2020) 107-114. DOI: https://doi.org/10.1080/17439884.2020.1761641

[40] J. Haidt, Digital technology under scrutiny, Nature, 578 (2020) 228-229.

[41] T.G. Hoog, L.M. Aufdembrink, N.J. Gaut, et al., Rapid Deployment of Smartphone-Based Augmented Reality Tools for Field And Online Education in Structural Biology, Biochemistry and Molecular Biology Education, 48 (2020) 448-451. https://doi.org/10.1002/bmb.21396 
Appendix: Journal type and ranking based on Scimago

\begin{tabular}{|c|c|c|c|c|}
\hline No & Year & Name & Journal subject & Rank \\
\hline 1. & 2012 & Chen C M and Tsai Y N & $\begin{array}{l}\text { Interactive instruction with } \\
\text { augmented reality }\end{array}$ & Q1 \\
\hline 2. & 2012 & Radu I & $\begin{array}{l}\text { Comparative review impact of } \\
\text { augmented reality }\end{array}$ & Proceeding \\
\hline 3. & 2013 & Di Serio Á Ibáñez M B and Kloos C D & $\begin{array}{l}\text { Impact augmented reality on } \\
\text { motivation }\end{array}$ & Q1 \\
\hline 4. & 2013 & Cheng $\mathrm{K} \mathrm{H}$ and Tsai C C & $\begin{array}{l}\text { Affordance augmented reality } \\
\text { in study }\end{array}$ & Q1 \\
\hline 5. & 2013 & $\begin{array}{l}\text { Wu H K Lee S W Y Chang H Y and } \\
\text { Liang J C }\end{array}$ & Challenges augmented reality & Q1 \\
\hline 6. & 2013 & $\begin{array}{l}\text { Bujak K R Radu I Catrambone R } \\
\text { MacIntyre B Zheng R and Golubski G }\end{array}$ & $\begin{array}{l}\text { Psychological study using } \\
\text { augmented reality }\end{array}$ & Q1 \\
\hline 7. & 2014 & $\begin{array}{l}\text { Huang W Shang J Chen J Huang Y and } \\
\text { Li G }\end{array}$ & $\begin{array}{l}\text { Augmented reality in Science } \\
\text { learning }\end{array}$ & Q3 \\
\hline 8. & 2014 & $\begin{array}{l}\text { Chiang } \mathrm{TH} \text { H Yang } \mathrm{S} J \mathrm{H} \text { and Hwang } \\
\text { G J }\end{array}$ & $\begin{array}{l}\text { Impact augmented reality on } \\
\text { achievements and motivation }\end{array}$ & Q1 \\
\hline 9. & 2014 & Sommerauer $\mathrm{P}$ and Müller $\mathrm{O}$ & $\begin{array}{l}\text { Augmented reality and } \\
\text { informal learning }\end{array}$ & Q1 \\
\hline 10. & 2014 & $\begin{array}{l}\text { Ibáñez M B Di Serio Á Villarán D and } \\
\text { Delgado Kloos C }\end{array}$ & $\begin{array}{l}\text { Experiment study using } \\
\text { augmented reality }\end{array}$ & Q1 \\
\hline 11. & 2015 & $\begin{array}{l}\text { D. Stoyanova, N. Kafadarova, S. } \\
\text { Stoyanova-Petrova }\end{array}$ & $\begin{array}{ll}\text { Enhancing } & \text { through } \\
\text { augmented reality } & \end{array}$ & Q4 \\
\hline 12. & 2015 & $\begin{array}{l}\text { J. Ferrer-Torregrosa, J. Torralba, } \\
\text { M. A. Jimenez, S. Garcı́a, J. M. Barcia }\end{array}$ & Development and assessment & Q1 \\
\hline 13. & 2016 & $\begin{array}{l}\text { Murat Akçayır, G€okçe Akçayır , } \\
\text { Hüseyin Miraç Pektas, Mehmet Akif } \\
\text { Ocak }\end{array}$ & Technology and laboratories & Q1 \\
\hline 14 & 2016 & Liu Y Holden D and Zheng D & $\begin{array}{l}\text { Analyzing student experience } \\
\text { learning with augmented } \\
\text { reality }\end{array}$ & - \\
\hline 15. & 2017 & Streitz $\mathrm{N}$ and Markopoulos $\mathrm{P}$ & Distributed interaction & Q1 \\
\hline 16. & 2018 & Karagozlu D & $\begin{array}{l}\text { Application and problem } \\
\text { solving skills }\end{array}$ & Q2 \\
\hline 17. & 2018 & $\begin{array}{l}\text { Wu P H Hwang G J Yang M L and Chen } \\
\mathrm{CH}\end{array}$ & $\begin{array}{l}\text { Impact augmented reality on } \\
\text { study }\end{array}$ & Q1 \\
\hline 18. & 2018 & Molnár G Szűts Z and Biró K, & $\begin{array}{l}\text { Use augmented reality in } \\
\text { learning }\end{array}$ & Q2 \\
\hline
\end{tabular}




\begin{tabular}{|c|c|c|c|c|}
\hline 19. & 2019 & Garzón J Pavón J and Baldiris S & $\begin{array}{l}\text { Systematic review augmented } \\
\text { reality }\end{array}$ & Q1 \\
\hline 20. & 2019 & $\begin{array}{l}\text { Papanastasiou G Drigas A Skianis C } \\
\text { Lytras M and Papanastasiou E }\end{array}$ & Effect of augmented reality & Q1 \\
\hline 21 & 2019 & Khan T Johnston K and Ophoff J & $\begin{array}{l}\text { Impact augmented reality on } \\
\text { learning motivation }\end{array}$ & Q3 \\
\hline 22. & 2019 & $\begin{array}{l}\text { Cabero-Almenara J Barroso-Osuna J } \\
\text { Llorente-Cejudo C and Martínez M D } \\
\text { M F }\end{array}$ & $\begin{array}{l}\text { Experience using augmented } \\
\text { reality }\end{array}$ & Q2 \\
\hline 23. & 2020 & $\begin{array}{l}\text { Weng C Otanga S Christianto S M and } \\
\text { Chu R J C }\end{array}$ & $\begin{array}{l}\text { Using augmented reality in } \\
\text { biology class }\end{array}$ & Q1 \\
\hline 24. & 2020 & Sandars J and Patel R & $\begin{array}{l}\text { Challenge online learning } \\
\text { during covid-19 }\end{array}$ & Q2 \\
\hline 25. & 2020 & Williamson B Eynon R and Potter J & $\begin{array}{l}\text { Impact digital technologies } \\
\text { during coronavirus }\end{array}$ & Q1 \\
\hline 26. & 2020 & Haidt J & $\begin{array}{l}\text { Digital technology under } \\
\text { pandemic }\end{array}$ & Q1 \\
\hline 27. & 2020 & $\begin{array}{l}\text { Hoog T G Aufdembrink L M Gaut N J } \\
\text { Sung R J Adamala K P and Engelhart A } \\
\text { E }\end{array}$ & $\begin{array}{l}\text { Effect using online study with } \\
\text { augmented reality tools }\end{array}$ & Q3 \\
\hline 28. & 2020 & Garfin D R & $\begin{array}{l}\text { Using technology } \\
\text { pandemic covid-19 }\end{array}$ & Q2 \\
\hline
\end{tabular}

